\title{
Halomonas saccharevitans sp. nov., Halomonas arcis sp. nov. and Halomonas subterranea sp. nov., halophilic bacteria isolated from hypersaline environments of China
}

\author{
Xue-Wei Xu, ${ }^{1} \dagger$ Yue-Hong $\mathrm{Wu},{ }^{1} \dagger$ Zhen Zhou, ${ }^{1}$ Chun-Sheng Wang, ${ }^{2}$ \\ Yu-Guang Zhou, ${ }^{3}$ Hui-Bin Zhang, ${ }^{4}$ Yong Wang ${ }^{1}$ and Min $\mathrm{Wu}^{1}$ \\ ${ }^{1}$ College of Life Sciences, Zhejiang University, Hangzhou 310058, People's Republic of China \\ 2Second Institute of Oceanography, State Oceanic Administration, Hangzhou 310012 , \\ People's Republic of China \\ ${ }^{3}$ Institute of Microbiology, Chinese Academy of Sciences, Beijing 100080, \\ People's Republic of China \\ ${ }^{4}$ Altun Mountain National Nature Reserve Administration, Kuerle 841000, \\ People's Republic of China
}

Correspondence Min Wu wumin@zju.edu.cn

\begin{abstract}
Three strains of Gram-negative, aerobic, neutrophilic and halophilic bacteria were isolated from samples of a salt lake on the Qinghai-Tibet Plateau and a subterranean saline well in the Si-Chuan Basin of China. These isolates, designated $A J 275^{\top}, A J 282^{\top}$ and $Z G 16^{\top}$, were investigated using a polyphasic approach. Based on 16S rRNA gene sequence analysis, the isolates could be affiliated to the genus Halomonas. Genomic DNA G + C contents were $65.9 \mathrm{~mol} \%$ for $A J 275^{\top}, 56.7 \mathrm{~mol} \%$ for $A J 282^{\top}$ and $57.6 \mathrm{~mol} \%$ for $Z \mathrm{ZG}^{\top} 6^{\top}$. The results of DNA-DNA hybridizations, fatty acid analysis and physiological and biochemical tests allowed the isolates to be differentiated genotypically and phenotypically from closely related species.

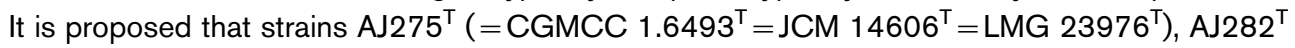

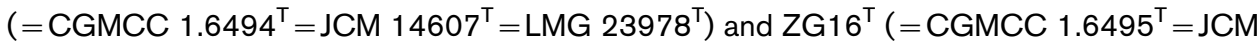
$14608^{\top}=$ LMG $23977^{\top}$ ) represent the type strains of three novel species in the genus Halomonas: Halomonas saccharevitans sp. nov., Halomonas arcis sp. nov. and Halomonas subterranea sp. nov., respectively.
\end{abstract}

The genus Halomonas, belonging to the family Halomonadaceae within the class Gammaproteobacteria, was originally proposed by Vreeland et al. (1980). During the past two decades, many Halomonas species have been isolated from different saline environments, such as saline or soda lakes (Franzmann et al., 1987; James et al., 1990; Mormile et al., 1999; Duckworth et al., 2000; Quillaguamán et al., 2004), solar salterns (Bouchotroch et al., 2001; Lim et al., 2004; Martínez-Checa et al., 2005; Lee et al., 2005), saline sands or soils (Romano et al., 1996; Martínez-Cánovas et al., 2004a, b; García et al., 2004), mineral pools (Romano et al., 2005), marine environments (Yoon et al., 2001; Kaye et al., 2004), animals (Romanenko et al., 2002), seafoods (Yoon et al., 2002), artificial sewage treatments (Berendes et al., 1996) and walls and mural paintings

tThese authors contributed equally to this work.

The GenBank/EMBL/DDBJ accession numbers for the 16S rRNA gene sequences of strains $A J 282^{\top}, Z G 16^{\top}$ and $A J 275^{\top}$ are EF144147, EF144148 and EF144149, respectively.
(Heyrman et al., 2002). Additionally, some bacteria that were assigned initially to other genera have been reclassified (Mellado et al., 1995; Dobson \& Franzmann, 1996). In total, 35 species of Halomonas have been described at the time of writing.

In this study, three novel halophilic bacteria are described using a polyphasic approach. Strains $\mathrm{AJ} 282^{\mathrm{T}}$ and $\mathrm{AJ} 275^{\mathrm{T}}$ were isolated from a water sample from Ayakekum salt lake $\left(37^{\circ} 33^{\prime} \mathrm{N} 89^{\circ} 42^{\prime} \mathrm{E}\right.$; $3884 \mathrm{~m}$ altitude) located in Altun Mountain on the Qinghai-Tibet Plateau, China. Strain $\mathrm{ZG}_{16}{ }^{\mathrm{T}}$ was isolated from subterranean hypersaline waters taken from a saline well located in Zigong $\left(29^{\circ} 3^{\prime} \mathrm{N} 105^{\circ} 7^{\prime}\right.$ E) in the Si-Chuan Basin, China.

The medium (HM) used for isolation and maintenance of the strains was that described by Ventosa et al. (1982). The medium ( $\mathrm{pH} 7.5)$ contained (\%, w/v): $\mathrm{NaCl}, 5.0 ; \mathrm{KCl}$, $0.2 ; \mathrm{MgSO}_{4} .7 \mathrm{H}_{2} \mathrm{O}, 0.1 ; \mathrm{CaCl}_{2} .2 \mathrm{H}_{2} \mathrm{O}, 0.036 ; \mathrm{NaBr}, 0.023$; $\mathrm{NaHCO}_{3}, 0.006$; yeast extract (Difco), 1.0; peptone (Difco), 0.5 ; glucose, 0.1 . Water samples were filtered through 
$0.45 \mu \mathrm{m}$ and $0.22 \mu \mathrm{m}$ filters in sequence. The $0.22 \mu \mathrm{m}$ membranes were added to HM medium and plated by using a tenfold dilution series method. Plates were incubated aerobically at $25^{\circ} \mathrm{C}$. After 3-7 days incubation, representative colonies were picked and maintained at $30^{\circ} \mathrm{C}$. Strains were purified by repeated restreaking; purity was confirmed by the uniformity of colony morphology. Cell morphology and motility were examined by optical microscopy (Olympus BX40). The optimal conditions for growth were determined in HM medium with 0-30\% (w/v) $\mathrm{NaCl}$. The $\mathrm{pH}$ range for growth was determined by adding the buffers MES ( $\mathrm{pH}$ 5.0-6.0), PIPES ( $\mathrm{pH}$ 6.5-7.0), Tricine $(\mathrm{pH} 7.5-8.5)$ and CHES ( $\mathrm{pH} 9.0-10.0)$ to HM medium at a concentration of $50 \mathrm{mM}$. The temperature range for growth was determined by incubating the strains at $4-55^{\circ} \mathrm{C}$.
Phenotypic characteristics, including oxidase and catalase reactions, $\mathrm{H}_{2} \mathrm{~S}$ production, hydrolysis of aesculin, gelatin, casein, DNA, starch, Tween 20, Tween 80, tyrosine and urea, indole production, gluconate oxidation, phenylalanine deamination, substrate utilization and acid production from sugars, were tested in HM medium according to the methods of Mata et al. (2002). Antimicrobial susceptibility tests were performed in liquid HM medium containing $50 \mu \mathrm{g}$ antimicrobial agent $\mathrm{ml}^{-1}$. Detailed results are given in the species description.

Fatty acid methyl esters were obtained from cells grown in $\mathrm{HM}$ medium for 1 day at $30^{\circ} \mathrm{C}$ and analysed by using GC/ MS (Kuykendall et al., 1988); data are given in Table 1. The $16 \mathrm{~S}$ rRNA genes were amplified as described previously $(\mathrm{Xu}$

Table 1. Differential phenotypic characteristics of the novel isolates and the type strains of related Halomonas species

Strains: $1, \mathrm{AJ} 282^{\mathrm{T}} ; 2, \mathrm{ZG}{ }^{\mathrm{T}}$; 3, AJ275 ${ }^{\mathrm{T}} ; 4$, H. sulfidaeris DSM $15722^{\mathrm{T}} ; 5$, H. hydrothermalis DSM $15725^{\mathrm{T}}$; 6, H. venusta CGMCC $1.2315^{\mathrm{T}}$; 7 , H. ventosae DSM $15911^{\mathrm{T}}$. +, Positive; -, negative; ND, not determined; TR, trace. Data were from our comparative tests. All strains were positive for catalase and gluconate oxidation and negative for indole production and hydrolysis of gelatin and Tween 80 .

\begin{tabular}{|c|c|c|c|c|c|c|c|}
\hline Characteristic & 1 & 2 & 3 & 4 & 5 & 6 & 7 \\
\hline Oxidase & - & - & + & + & + & + & + \\
\hline $\mathrm{H}_{2} \mathrm{~S}$ formation & + & + & - & - & $\mathrm{ND}$ & - & - \\
\hline Phenylalanine deamination & + & - & + & + & + & - & - \\
\hline \multicolumn{8}{|l|}{ Hydrolysis of: } \\
\hline Aesculin & - & - & - & - & - & - & + \\
\hline Casein & + & + & - & + & - & - & - \\
\hline Tween 20 & + & + & + & + & - & - & + \\
\hline Tyrosine & - & - & - & - & - & + & + \\
\hline Urea & - & + & - & - & + & + & - \\
\hline \multicolumn{8}{|l|}{ Utilization of: } \\
\hline Citrate & + & + & - & + & + & + & + \\
\hline Ethanol & + & - & - & + & - & + & - \\
\hline Histidine & - & + & - & - & - & - & - \\
\hline Isoleucine & - & - & + & + & + & + & ND \\
\hline Malate & + & + & - & + & + & + & + \\
\hline \multicolumn{8}{|l|}{ Acid production from: } \\
\hline Galactose & + & + & - & + & ND & + & + \\
\hline Glucose & + & + & - & + & + & + & + \\
\hline Inositol & - & + & - & + & + & + & + \\
\hline Maltose & + & + & - & + & ND & + & + \\
\hline Sorbitol & + & + & - & - & - & + & + \\
\hline Sucrose & + & + & - & - & ND & + & + \\
\hline \multicolumn{8}{|l|}{ Susceptibility to: } \\
\hline Nitrofurantoin & - & + & + & + & + & + & + \\
\hline Penicillin & - & - & + & + & - & - & - \\
\hline \multicolumn{8}{|c|}{ Major fatty acid methyl esters (\%): } \\
\hline $16: 1 \omega 7 c$ & 8.94 & 3.31 & 10.37 & 5.75 & 3.84 & 9.84 & 11.77 \\
\hline $16: 0$ & 17.89 & 21.30 & 20.60 & 18.12 & 17.79 & 9.38 & 21.62 \\
\hline $18: 1 \omega 7 c$ & 30.03 & 29.46 & 30.65 & 42.89 & 36.46 & 42.36 & 27.11 \\
\hline $18: 0$ & 11.41 & 12.42 & 14.78 & $\mathrm{TR}$ & 14.26 & 13.92 & 10.90 \\
\hline $19: 0$ cyclo $\omega 8 c$ & 9.03 & 11.57 & 4.42 & 7.37 & TR & $\mathrm{TR}$ & 6.65 \\
\hline
\end{tabular}


et al., 2005) with primers 1 (5'-AGAGTTTGATCCTGGCTCAG-3'; positions 8-27 according to the Escherichia coli 16S rRNA gene) and 2 (5'-GGTTACCTTGTTACGACTT-3'; 1510-1492).

The sequence was compared with closely related sequences of reference organisms from the FASTA network service. Sequence data were aligned with CLUSTAL W 1.8 (Thompson et al., 1994). Phylogenetic trees were constructed by the neighbour-joining method with the MEGA3 program package (Kumar et al., 2004). The DNA G + C content was determined by thermal denaturation $\left(T_{\mathrm{m}}\right)$ (Marmur \& Doty, 1962) using E. coli K12 DNA as the calibration standard. DNA-DNA hybridizations were performed by the thermal denaturation and renaturation method of De Ley et al. (1970) as modified by Huß et al. (1983), using a Beckman DU 800 spectrophotometer.

$16 \mathrm{~S}$ rRNA gene sequence analysis indicated that strains $\mathrm{AJ} 275^{\mathrm{T}}, \mathrm{AJ} 282^{\mathrm{T}}$ and $\mathrm{ZG16}{ }^{\mathrm{T}}$ clustered within the genus Halomonas (Fig. 1). Strain AJ $275^{\mathrm{T}}$ exhibited the closest phylogenetic affinity and highest sequence similarity to Halomonas ventosae DSM $15911^{\mathrm{T}}(97.6 \%) .16 \mathrm{~S}$ rRNA gene sequence similarity values between strain $\mathrm{AJ} 275^{\mathrm{T}}$ and other Halomonas species were below $96.5 \%$. The DNA G+C content of strain $\mathrm{AJ} 275^{\mathrm{T}}$ ( $\left.65.9 \mathrm{~mol} \%\right)$ was close to the upper limit of typical values for Halomonas species (52-68 mol\%; Franzmann et al., 1988), but was notably lower than that of H. ventosae DSM $15911^{\mathrm{T}}$ (73.4 mol\%; Martínez-Cánovas et al., 2004a). DNA-DNA hybridization was carried out at $80{ }^{\circ} \mathrm{C}$. The DNA-DNA relatedness level between strain AJ275 ${ }^{\mathrm{T}}$ and H. ventosae DSM $15911^{\mathrm{T}}$ was $17 \%$. Phylogenetic analysis based on 16S rRNA gene sequence comparison showed that strains $\mathrm{AJ} 282^{\mathrm{T}}$ and $\mathrm{ZG} 16^{\mathrm{T}}$ could be placed in a parallel branch with Halomonas sulfidaeris and Halomonas hydrothermalis with high bootstrap values (Fig. 1). The $16 \mathrm{~S}$ rRNA gene sequence similarities of these two novel isolates were around $97 \%$ to $H$. sulfidaeris DSM $15722^{\mathrm{T}}$ and H. hydrothermalis DSM $15725^{\mathrm{T}}$. DNA-DNA relatedness between the novel isolates and H. sulfidaeris DSM $15722^{\mathrm{T}}$, H. hydrothermalis DSM $15725^{\mathrm{T}}$ and Halomonas venusta CGMCC $1.2315^{\mathrm{T}}$ was less than $50 \%$ (Table 2). In addition, comparison of phenotypic properties (Table 1) also indicated differences between the novel isolates and other Halomonas species, such as hydrolysis of substrates, acid production from sugars, sensitivity to antimicrobial agents and fatty acid composition.

Based on 16S rRNA gene sequence analysis, as well as DNADNA hybridization data and differential phenotypic properties, it is concluded that strains $\mathrm{AJ} 275^{\mathrm{T}}, \mathrm{AJ} 282^{\mathrm{T}}$ and $\mathrm{ZG} 16^{\mathrm{T}}$ represent three novel species within the genus Halomonas, Halomonas saccharevitans sp. nov., Halomonas arcis sp. nov. and Halomonas subterranea sp. nov., respectively.

\section{Description of Halomonas saccharevitans sp. nov.}

Halomonas saccharevitans (sac.char.e' vi.tans. L. n. saccharon $-i$ a kind of sugar; L. part. adj. evitans avoiding; N.L. part. adj. saccharevitans sugar avoiding, because it uses very few sugars).

Gram-negative. Aerobic. Oxidase- and catalase-positive. Motile cocci, $0.8-1.2 \mu \mathrm{m}$ in diameter. Young cultures show ovoid-like cells ( $1-2 \mu \mathrm{m}$ wide and $2-4 \mu \mathrm{m}$ long). Colonies on complex agar medium are 1-2 $\mathrm{mm}$ in diameter, smooth, circular, elevated and light yellow after 2 days. Moderately halophilic. $\mathrm{NaCl}$ concentration for growth is between 0.5 and $15.0 \%(\mathrm{w} / \mathrm{v})$, with optimum growth at $3.0-7.5 \%$. Grows at $\mathrm{pH} 6.0-10.0$ and $4-48{ }^{\circ} \mathrm{C}$ (optimum growth at $\mathrm{pH} 7.0-8.0$ and $30^{\circ} \mathrm{C}$ ). Tween 20 is hydrolysed. Aesculin, casein, DNA, gelatin, starch, Tween 80 and tyrosine are not hydrolysed. Phenylalanine deamination and gluconate

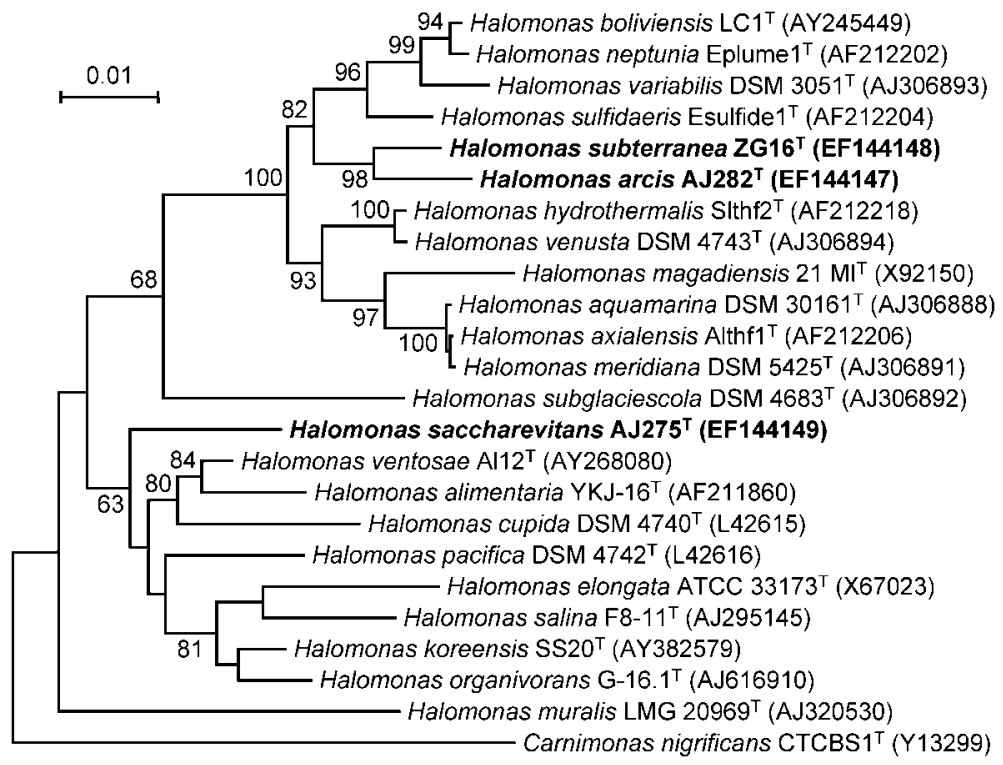

Fig. 1. Neighbour-joining tree based on 16S rRNA gene sequences, showing the phylogenetic relationships of the novel isolates and related taxa. Bootstrap values are based on 1000 replicates; only values $>60 \%$ are show. Bar, 0.01 substitutions per nucleotide position. 
Table 2. DNA $\mathrm{G}+\mathrm{C}$ content $\left(T_{\mathrm{m}}\right)$ and DNA-DNA hybridization between the novel strains and related species of the genus Halomonas

\begin{tabular}{|lccc|}
\hline Strain & $\begin{array}{c}\text { DNA G+C } \\
\text { content (mol\%) }\end{array}$ & \multicolumn{2}{c|}{ DNA-DNA hybridization with: (\%) } \\
\cline { 3 - 4 } & & AJ282 $^{\mathbf{T}}$ & ZG16 $^{\mathbf{T}}$ \\
\hline AJ282 & $56.7 \pm 0.3$ & 100 & 46 \\
ZG16 & $57.6 \pm 1.1$ & 46 & 100 \\
H. sulfidaeris DSM $15722^{\mathrm{T}}$ & $56.0^{*}$ & 48 & 49 \\
H. hydrothermalis DSM $15725^{\mathrm{T}}$ & $56.3^{*}$ & 25 & 7 \\
H. venusta CGMCC $1.2315^{\mathrm{T}}$ & $\mathrm{ND}$ & 25 & $\mathrm{ND}$ \\
\hline
\end{tabular}

ND, Not determined.

${ }^{\star}$ Data from Kaye et al. (2004).

oxidation are positive. Negative for production of indole and urease. $\mathrm{H}_{2} \mathrm{~S}$ is not produced from thiosulfate. Chemoorganotrophic. Casamino acids are required for growth. The following substrates are utilized for growth: glycerol, fumarate, alanine, aspartate, glutamate, isoleucine, serine and valine. No growth is observed on arabinose, cellobiose, fructose, galactose, glucose, lactose, maltose, mannose, melezitose, rhamnose, ribose, sorbose, sucrose, trehalose, xylose, adonitol, ethanol, inositol, mannitol, sorbitol, salicin, acetate, citrate, formate, gluconate, malate, malonate, propionate, succinate, arginine, glycine, histidine, leucine, lysine, methionine or ornithine. Susceptible to ampicillin, carbenicillin, cefotaxime, chloramphenicol, erythromycin, nalidixic acid, nitrofurantoin, penicillin, polymyxin B and treptomycin, but not to kanamycin, neomycin, nystain, rifampicin or streptomycin. Principal fatty acids (greater than $5 \%$ ) are $18: 1 \omega 7 c, 16: 0,18: 0$ and $16: 1 \omega 7 c$.

The type strain is $\mathrm{AJ} 275^{\mathrm{T}}$ (=CGMCC $1.6493^{\mathrm{T}}=\mathrm{JCM}$ $14606^{\mathrm{T}}=\mathrm{LMG} 23976^{\mathrm{T}}$ ), isolated from a water sample taken from a salt lake on the Qinghai-Tibet Plateau, China. The DNA G $+\mathrm{C}$ content of strain $\mathrm{AJ} 275^{\mathrm{T}}$ is $65.9 \pm$ $0.3 \mathrm{~mol} \%\left(T_{\mathrm{m}}\right)$.

\section{Description of Halomonas arcis sp. nov.}

Halomonas arcis ( $\mathrm{ar}^{\prime}$ cis. L. gen. n. arcis of a height, summit or peak, referring to the isolation of the organism from a salt lake on the Qinghai-Tibet Plateau).

Gram-negative and motile. Young cultures show rod-like cells $(0.5-1.0 \times 2.0-4.0 \mu \mathrm{m})$. Colonies on complex agar medium are smooth, circular, elevated and cream. Halotolerant. $\mathrm{NaCl}$ concentration for growth is between 0 and $20 \%(\mathrm{w} / \mathrm{v})$, with optimum growth at $1-5 \%(\mathrm{w} / \mathrm{v})$. Grows at $\mathrm{pH}$ 6.0-10.0 and $4-48^{\circ} \mathrm{C}$ (optimum growth at $\mathrm{pH} 7.0-8.0$ and $30^{\circ} \mathrm{C}$ ). Catalase is produced, but not oxidase. Tween 20 and casein are hydrolysed. $\mathrm{H}_{2} \mathrm{~S}$ is produced from thiosulfate. Aesculin, DNA, gelatin, starch, Tween 80 and tyrosine are not hydrolysed. Phenylalanine deamination and gluconate oxidation are positive. Indole and urease production are negative. Chemo-organotrophic. Casamino acids are required for growth. Acid is produced from galactose and glucose and, to a lesser extent, from arabinose, fructose, maltose, mannitol, melezitose, sorbitol, sucrose and trehalose. No growth is observed on cellobiose, lactose, mannose, rhamnose, ribose or xylose. The following substrates are utilized for growth: xylose, ethanol, glycerol, acetate, citrate, fumarate, gluconate, malate, malonate, propionate, succinate, alanine, arginine, aspartate, glutamate, lysine, ornithine and valine. Susceptible to chloramphenicol, erythromycin, nalidixic acid, polymyxin B and treptomycin, but not to ampicillin, kanamycin, neomycin, nitrofurantoin, nystain, penicillin, rifampicin or streptomycin. Principal fatty acids (greater than 5\%) are $18: 1 \omega 7 c$, $16: 0,18: 0,19: 0$ cyclo $\omega 8 c$ and $16: 1 \omega 7 c$.

The type strain is AJ282 ${ }^{\mathrm{T}}$ (=CGMCC $1.6494^{\mathrm{T}}=\mathrm{JCM}$ $14607^{\mathrm{T}}=\mathrm{LMG} 23978^{\mathrm{T}}$ ), isolated from a water sample taken from a salt lake located in Altun Mountain on the Qinghai-Tibet Plateau, China. The DNA G $+\mathrm{C}$ content of strain $\mathrm{AJ} 282^{\mathrm{T}}$ is $56.7 \pm 0.3 \mathrm{~mol} \%\left(T_{\mathrm{m}}\right)$.

\section{Description of Halomonas subterranea sp. nov.}

Halomonas subterranea (sub.ter.ra'ne.a. L. fem. adj. subterranea underground, subterranean, referring to the isolation of the organism from the subterranean brines).

Gram-negative and motile. Young cultures show rod-like cells $(0.5-1.0 \times 3.0-5 \mu \mathrm{m})$. Colonies on complex agar medium are smooth, circular, elevated and cream. Halotolerant. $\mathrm{NaCl}$ concentration for growth is between 0 and $15 \%(\mathrm{w} / \mathrm{v})$, with optimum growth at $1-5 \%(\mathrm{w} / \mathrm{v})$. Grows at $\mathrm{pH} 6.0-10.0$ and $4-48^{\circ} \mathrm{C}$ (optimum growth at $\mathrm{pH} 7.0-8.0$ and $30^{\circ} \mathrm{C}$ ). Catalase is produced, but not oxidase. Tween 20 , casein and urea are hydrolysed. $\mathrm{H}_{2} \mathrm{~S}$ is produced from thiosulfate. Aesculin, DNA, gelatin, starch, Tween 80 and tyrosine are not hydrolysed. Gluconate oxidation is positive. Indole production and phenylalanine deamination are negative. Chemo-organotrophic. Casamino acids are required for growth. Acid is produced from arabinose, galactose and glucose and, to a lesser extent, from fructose, inositol, maltose, mannitol, melezitose, sorbitol, sucrose and trehalose. No growth is observed on cellobiose, lactose, 
mannose, rhamnose, ribose, sorbose or xylose. The following substrates are utilized for growth: xylose, glycerol, acetate, citrate, fumarate, gluconate, malate, succinate, alanine, arginine, aspartate, glutamate, histidine and lysine. Susceptible to chloramphenicol, erythromycin, nalidixic acid, nitrofurantoin, polymyxin $B$ and treptomycin, but not to ampicillin, kanamycin, neomycin, nystain, penicillin, rifampicin or streptomycin. Principal fatty acids (greater than $5 \%)$ are $18: 1 \omega 7 c, 16: 0,18: 0$ and $19: 0$ cyclo $\omega 8 c$.

The type strain is $\mathrm{ZG}^{\mathrm{T}}{ }^{\mathrm{T}}$ (=CGMCC $1.6495^{\mathrm{T}}=\mathrm{JCM}$ $14608^{\mathrm{T}}=\mathrm{LMG} 23977^{\mathrm{T}}$ ), isolated from hypersaline waters taken from a subterranean saline well on the Si-Chuan Basin, China. The DNA G $+\mathrm{C}$ content of strain $\mathrm{ZG}^{\mathrm{T}}{ }^{\mathrm{T}}$ is $57.6 \pm 1.1 \mathrm{~mol} \%\left(T_{\mathrm{m}}\right)$.

\section{Acknowledgements}

We thank Jean Euzéby for his help with the specific etymology and nomenclature. This work was supported by grants from the Major State Basic Research Development Program of China (973 Program) (grant no. 2004CB719604-3) and the National Natural Science Foundation of China (grant no. 30670048).

\section{References}

Berendes, F., Gottschalk, G., Heine-Dobbernack, E., Moore, E. R. B. \& Tindall, B. J. (1996). Halomonas desiderata sp. nov., a new alkaliphilic, halotolerant and denitrifying bacterium isolated from a municipal sewage works. Syst Appl Microbiol 19, 158-167.

Bouchotroch, S., Quesada, E., Moral, A. D., Llamas, I. \& Béjar, V. (2001). Halomonas maura sp. nov., a novel moderately halophilic, exopolysaccharide-producing bacterium. Int J Syst Evol Microbiol 51, 1625-1632.

De Ley, J., Cattoir, H. \& Reynaerts, A. (1970). The quantitative measurement of DNA hybridization from renaturation rates. Eur J Biochem 12, 133-142.

Dobson, S. J. \& Franzmann, P. D. (1996). Unification of the genera Deleya (Baumann et al. 1983), Halomonas (Vreeland et al. 1980), and Halovibrio (Fendrich 1988) and the species Paracoccus halodenitrificans (Robinson and Gibbons 1952) into a single genus, Halomonas, and placement of the genus Zymobacter in the family Halomonadaceae. Int J Syst Bacteriol 46, 550-558.

Duckworth, A. W., Grant, W. D., Jones, B. E., Meijer, D., Márquez, M. C. \& Ventosa, A. (2000). Halomonas magadii sp. nov., a new member of the genus Halomonas, isolated from a soda lake of the East African Rift Valley. Extremophiles 4, 53-60.

Franzmann, P. D., Burton, H. R. \& McMeekin, T. A. (1987). Halomonas subglaciescola, a new species of halotolerant bacteria isolated from Antarctica. Int J Syst Bacteriol 37, 27-34.

Franzmann, P. D., Wehmeyer, U. \& Stackebrandt, E. (1988). Halomonadaceae fam. nov., a new family of the class Proteobacteria to accommodate the genera Halomonas and Deleya. Syst Appl Microbiol 11, 16-19.

Garcia, M. T., Mellado, E., Ostos, J. C. \& Ventosa, A. (2004). Halomonas organivorans sp. nov., a moderate halophile able to degrade aromatic compounds. Int J Syst Evol Microbiol 54, 1723-1728.

Heyrman, J., Balcaen, A., De Vos, P. \& Swings, J. (2002). Halomonas muralis sp. nov., isolated from microbial biofilms colonizing the walls and murals of the Saint-Catherine chapel (Castle Herberstein, Austria). Int J Syst Evol Microbiol 52, 2049-2054.
Huß, V. A. R., Festl, H. \& Schleifer, K. H. (1983). Studies on the spectrophotometric determination of DNA hybridization from renaturation rates. Syst Appl Microbiol 4, 184-192.

James, S. R., Dobson, S. J., Franzmann, P. D. \& McMeekin, T. A. (1990). Halomonas meridiana, a new species of extremely halotolerant bacteria isolated from Antarctic saline lakes. Syst Appl Microbiol 13, 270-278.

Kaye, J. Z., Márquez, M. C., Ventosa, A. \& Baross, J. A. (2004). Halomonas neptunia sp. nov., Halomonas sulfidaeris sp. nov., Halomonas axialensis sp. nov. and Halomonas hydrothermalis sp. nov.: halophilic bacteria isolated from deep-sea hydrothermalvent environments. Int J Syst Evol Microbiol 54, 499-511.

Kumar, S., Tamura, K. \& Nei, M. (2004). MEGA3: integrated software for molecular evolutionary genetics analysis and sequence alignment. Brief Bioinform 5, 150-163.

Kuykendall, L. D., Roy, M. A., O'Neill, J. J. \& Devine, T. E. (1988). Fatty acids, antibiotic resistance, and deoxyribonucleic acid homology groups of Bradyrhizobium japonicum. Int J Syst Bacteriol 38, 358-361.

Lee, J.-C., Jeon, C.-O., Lim, J.-M., Lee, S.-M., Lee, J.-M., Song, S.-M., Park, D.-J., Li, W.-J. \& Kim, C.-J. (2005). Halomonas taeanensis sp. nov., a novel moderately halophilic bacterium isolated from a solar saltern in Korea. Int J Syst Evol Microbiol 55, 2027-2032.

Lim, J.-M., Yoon, J.-H., Lee, J.-C., Jeon, C.-O., Park, D.-J., Sung, C. \& Kim, C.-J. (2004). Halomonas koreensis sp. nov., a novel moderately halophilic bacterium isolated from a solar saltern in Korea. Int J Syst Evol Microbiol 54, 2037-2042.

Marmur, J. \& Doty, P. (1962). Determination of the base composition of deoxyribonucleic acid from its thermal denaturation temperature. J Mol Biol 5, 109-118.

Martínez-Cánovas, M. J., Quesada, E., Llamas, I. \& Béjar, V. (2004a). Halomonas ventosae sp. nov., a moderately halophilic, denitrifying, exopolysaccharide-producing bacterium. Int J Syst Evol Microbiol 54, 733-737.

Martínez-Cánovas, M. J., Béjar, V., Martínez-Checa, F. \& Quesada, E. (2004b). Halomonas anticariensis sp. nov., from Fuente de Piedra, a saline-wetland wildfowl reserve in Málaga, southern Spain. Int J Syst Evol Microbiol 54, 1329-1332.

Martínez-Checa, F., Bẻjar, V., Martínez-Cánovas, M. J., Llamas, I. \& Quesada, E. (2005). Halomonas almeriensis sp. nov., a moderately halophilic, exopolysaccharide-producing bacterium from Cabo de Gata, Almería, south-east Spain. Int J Syst Evol Microbiol 55, 2007-2011.

Mata, J. A., Martinez-Canovas, J., Quesada, E. \& Bejar, V. (2002). A detailed phenotypic characterisation of the type strains of Halomonas species. Syst Appl Microbiol 25, 360-375.

Mellado, E., Moore, E. R. B., Nieto, J. J. \& Ventosa, A. (1995). Phylogenetic inferences and taxonomic consequences of $16 \mathrm{~S}$ ribosomal DNA sequence comparison of Chromohalobacter marismortui, Volcaniella eurihalina, and Deleya salina and reclassification of $V$. eurihalina as Halomonas eurihalina comb. nov. Int J Syst Bacteriol 45, 712-716.

Mormile, M. R., Romine, M. F., Garcia, M. T., Ventosa, A., Bailey, T. J. \& Peyton, B. M. (1999). Halomonas campisalis sp. nov., a denitrifying, moderately haloalkaliphilic bacterium. Syst Appl Microbiol 22, 551-558.

Quillaguamán, J., Hatti-Kaul, R., Mattiasson, B., Alvarez, M. T. \& Delgado, O. (2004). Halomonas boliviensis sp. nov., an alkalitolerant, moderate halophile isolated from soil around a Bolivian hypersaline lake. Int J Syst Evol Microbiol 54, 721-725.

Romanenko, L. A., Schumann, P., Rohde, M., Mikhailov, V. V. \& Stackebrandt, E. (2002). Halomonas halocynthiae sp. nov., isolated 
from the marine ascidian Halocynthia aurantium. Int J Syst Evol Microbiol 52, 1767-1772.

Romano, I., Nicolaus, B., Lama, L., Manca, M. C. \& Gambacorta, A. (1996). Characterization of a haloalkalophilic strictly aerobic bacterium, isolated from Pantelleria Island. Syst Appl Microbiol 19, 326-333.

Romano, I., Gioradano, A., Lama, L., Nicolaus, B. \& Gambacorta, A. (2005). Halomonas campaniensis sp. nov., a haloalkaliphilic bacterium isolated from a mineral pool of Campania Region, Italy. Syst Appl Microbiol 28, 610-618.

Thompson, J. D., Higgins, D. G. \& Gibson, T. J. (1994). CLUSTAL W: improving the sensitivity of progressive multiple sequence alignment through sequence weighting, position-specific gap penalties and weight matrix choice. Nucleic Acids Res 22, 4673-4680.

Ventosa, A., Quesada, E., Rodriguez-Valera, F., Ruiz-Berraquero, F. \& Ramos-Cormenzana, A. (1982). Numerical taxonomy of moderately halophilic Gram-negative rods. J Gen Microbiol 128, 1959-1968.

Vreeland, R. H., Litchfield, C. D., Martin, E. L. \& Elliot, E. (1980). Halomonas elongata, a new genus and species of extremely salttolerant bacteria. Int J Syst Bacteriol 30, 485-495.

Xu, X.-W., Wu, M. \& Huang, W.-D. (2005). Isolation and characterization of a novel strain of Natrinema containing a bop gene. J Zhejiang Univ Sci B 6, 142-146.

Yoon, J.-H., Choi, S.-H., Lee, K.-C., Kho, Y.-H., Kang, K.-H. \& Park, Y.-H. (2001). Halomonas marisflavae sp. nov., a halophilic bacterium isolated from the Yellow Sea in Korea. Int J Syst Evol Microbiol 51, 1171-1177.

Yoon, J.-H., Lee, K.-C., Kho, Y.-H., Kang, K.-H., Kim, C.-J. \& Park, Y.-H. (2002). Halomonas alimentaria sp. nov., isolated from jeotgal, a traditional Korean fermented seafood. Int J Syst Evol Microbiol 52, 123-130. 